\title{
Capital Market Integration In Some Asean Countries Revisited
}

\author{
Robiyanto Robiyanto* and Rihfenti Ernayani \\ Faculty of Economics and Business, Satya Wacana Christian University \\ e-mail: robiyanto@staff.uksw.edu \\ Faculty of Economics, Universitas Balikpapan \\ e-mail: rihfenti@uniba-bpn.ac.id \\ * Corresponding Author
}

\begin{abstract}
Financial market integration in Southern Asia especially in ASEAN main member countries still attractive to scrunitized. Most of these countries were devastated during severe regional financial crisis in 1997 but global financial crisis in 2008 have different impact toward these countries. The finding shows that comovement were exist among Indonesia, Malaysia, Singapore and Thailand's capital market during January 1997 to December 2013 period. Comovement still exist during post Asian financial Crisis 1997 and post global financial crisis 2008 period. This study conclude also that degree of integration between some ASEAN capital markets have fading out after global financial crisis in 2008. Hence, investor could formulate a portfolio which consist of stocks across ASEAN capital markets.
\end{abstract}

Keywords: Capital market integration; Contagion effect, Vector Autoregression (VAR); Granger Causality Test; Vector Error Correction Model (VECM); ASEAN.

JEL Classification : G11; G15.

\section{INTRODUCTION}

Financial integration is a unified part of the ASEAN's objective to commence ASEAN Economic Community (AEC). The blue of the AEC itself had been agreed by all the top leaders of the ASEAN countries in 2007 (Robiyanto, Hersugondo, \& Chotijah, 2016). Basically, the blue print underlines some preceding stages to establish the AEC before it will be officially declared in 2015. Those stages include liberalization planning in the financial service sectors among the ASEAN countries which aims to accelerate the development and integration of capital market. One of its significant steps is the elimination or even the omission of capital flow constraints to achieve a more open capital flow in the ASEAN region (Volz, 2013).

It has to be admitted that, on the one hand, the financial integration shall give positive benefits and contributions to the development of the financial sectors among the ASEAN countries where most are still considered as developing countries. For instance, the integration will help the investors to predict the future movement of assets in ASEAN region (Suganda \& Soetrisno, 2016; Suryanta, 2011). However, on the other hand, there are substantial risks following the liberations of capital traffic and finance. One of its possible risks is a contagion effect since a collapse of one capital market shall immediately affect the other ones which are integrated and vise versa.

Jurnal Manajemen/Volume XXII, No. 02, Juni 2018:... 
Some researches on capital market integration in the ASEAN region have actually been conducted. Among those are Ibrahim (2006); Karim and Karim (2012); Kenani, Purnomo, and Maoni (2013); Mulyadi (2012); Palac-McMiken (1997); Roca, Selvanathan, and Shepherd (1998); Suryanta (2011). Overall, the results of those researches were slightly diverse. For instance, Palac-McMiken (1997); Roca et al. (1998); Suryanta (2011) found that most of the stock exchanges in ASEAN tended to be integrated one to another except Indonesia stock exchange. A slightly different result was elaborated by Karim and Karim (2012) where they found that all the ASEAN's stock exchanges tended to be integrated one to another included the Indonesia stock exchange. They added that the integration was even much clearer after the US financial crisis (subprime mortgage) occurred.

However, those researches above have not review the integration of capital markets in ASEAN region during the period of post US financial crisis (subprime mortgage). Actually, Mulyadi (2012) and Karim and Karim (2012) had included the period, yet they did not divide the period into pre and post US financial crisis. Compared to others, Karim and Karim (2012) took a further step by dividing their period of researches into pre Asia financial crisis 1997, post Asia financial crisis 1997, and post US financial crisis (subprime mortgage) 2008. December 2010 was the final period used by Karim and Karim (2012) as their research data. Based on the assumptions that a research on the integration of capital markets in ASEAN region using the latest data is still required, this study attempts to review the integration of some capital markets in ASEAN region like Singapore Stock Exchange, Indonesia Stock Exchange, Kuala Lumpur Stock Exchange, Stock Exchange Thailand until the period of December 2013.

Capital Market Integration and Some Previous Studies. The most common definition of "financially integrated market" was drawn by Baele, Ferrando, Hordahl, Krylova, and Monnet (2004) and Weber (2006) where they described that a market of an instrument and financial service are integrated completely when all the potential parties who are participating in the market have similar characteristics as follows: (1) facing a set of single rules when they are about to carry out particular instrument/financial service transactions; (2) possessing an equal access for the previously mentioned instruments/financial services; (3) equally treated in the market.

In line with Baele et al. (2004); Weber (2006), Valle (2000) stated that capital market could experience comovement for some underlying economic factors that reflected the general condition of the global finance and that systematically affected all markets around the world. In addition, comovement occurred in some countries were also affected by market deregulation and liberalization, communication technology and trading system developments, innovations in financial products and services, and the rising activities of the multinational companies in the international market (Robiyanto, Wahyudi, \& Pangestuti, 2017b).

Jorion and Schwartz (1986) stated that a capital market was internationally integrated when assets with identical risks had the same prices as well although they were traded in a different capital market. It means that risk and return are acknowledged internationally and the stock movements in the capital market are not only affected by domestic factors but also the global stock movements happening in the capital markets all over the globe (Robiyanto, Wahyudi, \& Pangestuti, 2017a). Similarly, Bekaert, Harvey, 
and Lundblad (2007) also stated that in a market with high level of integration and contagion effect, it will expose high levels of comovement and interrelation. Oppose to the integrated capital market is segmented capital market. A market is considered as segmented when it has low interrelation with other capital markets (Bilson, 2000; Robiyanto, 2017).

Meanwhile, several researches related to the integration of capital market in ASEAN have been previously done by Ibrahim (2006); Karim and Karim (2012); Kenani et al. (2013); Mulyadi (2012); Palac-McMiken (1997); Roca et al. (1998); Suryanta (2011). Based on the data obtained between January 1987 to October 1995, Palac-McMiken (1997) reviewed the integration of some capital markets in the ASEAN region included Jakarta Stock Exchange, Philippines Stock Exchange, Kuala Lumpur Stock Exchange, Singapore Stock Exchange, and Stock Exchange Thailand. Though the cointegration analysis utilization, it found that all the markets were interrelated one and another except the Jakarta Stock Exchange (Indonesia). An additional result showed that the capital markets during the 1987-1995 period was considered as collectively inefficient.

At nearly the same period with Palac-McMiken (1997), i.e. 1988 - 1995, Roca et al. (1998) also studied the integration of capital markets among the ASEAN member countries. Similarly, Roca et al. (1998) also found that Jakarta Stock Exchange did not show any interrelations with any other capital markets in the region for both in long nor short terms. Hence, the interrelation among the capital markets, except Jakarta Stock Exchange, was only detected in the short term but not in the long term.

By taking the longer period of study, i.e. January 1988 to December 2003, Ibrahim (2006) attempted to explore the same capital markets with Vector Autoregressive (VAR) as its main instrument utilized. In addition, it also tried to capture a different viewpoint, i.e. the effects of the US and Japan capital markets toward ASEAN capital markets. It showed that most capital markets in ASEAN were predominantly affected by the US than Japan capital market. Empirical evidence also revealed that most ASEAN capital markets were vulnerable toward international financial crisis. It was proven when turbulences occurred in the US capital market that affected the ASEAN markets significantly. However, dramatic positive changes occurred among the most influential capital markets in the world contributed insignificantly toward the ASEAN markets.

VAR instrument was also utilized by Suryanta (2011) to review the integration of capital markets among ASEAN countries like Indonesia, Malaysia, Singapore, Thailand, and Phillipines. Although this study used the latest data obtained in between January 2004 to December 2009 period, but the results found were quite similar to those with PalacMcMiken (1997) and Roca et al. (1998). Comovement and dynamic interrelation between Indonesia capital market with Malaysia, Singapore, Thailand, and Philippines capital markets were not found. Furthermore, Suryanta (2011) believed that domestic factors gave more contributions toward Indonesia capital market instead of the external ones.

A more detailed research on the integration among Indonesia, Malaysia, Singapore, Thailand, and Philippines capital markets was elaborated by Karim and Karim (2012). They used data obtained during January 1988 to December 2010 which then divided into three main periods, i.e. pre 1997, post 1997, and also post US financial crisis (subprime mortgage). Karim and Karim (2012) concluded that the integration among ASEAN capital markets were a lot stronger after the US financial crisis (subprime mortgage). 
A more specific research was done by Mulyadi (2012) where he attempted to scrutinize the influences of the US and Japan capital markets toward Indonesia stock market. By using the data obtained during January 2004 to December 2008 period, he found a consistent result with Ibrahim (2006) in which the Indonesia capital market was significantly affected by the conditions of those two more advanced capital markets. Hence, the research also proved the relation between the US and Indonesia capital markets was considered as one way traffic where the US took its domination toward Indonesia capital market. A slightly different result was observed on the relation between Japan and Indonesia capital market. Here, an interrelation between these two markets occurred where they affected one and another.

The latest research on Indonesia capital market was conducted by Kenani et al. (2013). This research attempted to scrutinize the integration between China and Indonesia capital markets during the post global financial crisis 2008 period. The result showed that two ways traffic of relation between these two markets sustained before and after the crisis occurred. Furthermore, it also proved that Japan capital market gave more significant influences toward Indonesia capital market before and after the crisis, while the US market's effects stopped after the global crisis ended. Kenani et al. (2013) concluded that, after the global financial crisis 2008, the influences from China toward Indonesia capital market grew higher and higher, while from the US were decreasing.

VAR, Cointegration Test, VECM, and Granger Causality Test. VAR was applied to observe the short term connection. A VAR system with order $\mathrm{k}$ formulated as VAR (k) with $\mathrm{n}$ variable is relevant to these equation as follows (Suryanta, 2011):

$\mathrm{y}_{\mathrm{t}}=\alpha+\Theta_{1} \mathrm{y}_{\mathrm{t}-1}+\ldots+\Theta_{\mathrm{k}} \mathrm{y}_{\mathrm{t}-\mathrm{k}}+\varepsilon_{\mathrm{nt}}$

where $\Theta_{\mathrm{k}}=\left[\begin{array}{ccc}\theta_{11, \mathrm{k}} & \ldots & \theta_{1 \mathrm{n}, \mathrm{k}} \\ \theta_{\mathrm{n} 1, \mathrm{k}} & \ldots & \theta_{\mathrm{nn}, \mathrm{k}}\end{array}\right]$

and $\mathrm{y}_{\mathrm{t}}=\left(\mathrm{y} 1_{\mathrm{t}}, \mathrm{y} 2_{\mathrm{t}}, \ldots, \mathrm{y}_{\mathrm{nt}}\right)$

Four variables $(\mathrm{n}=$ four (4)) with lag (k) equals to one (1) were used in this study. Thus, the simplified model of VAR with $\mathrm{y}_{\mathrm{nt}}$ notation where $\mathrm{n}=4$ was replaced with $\mathrm{R}_{\mathrm{I}, \mathrm{t}} ; \mathrm{R}_{\mathrm{S}, \mathrm{t}} ; \mathrm{R}_{\mathrm{M}, \mathrm{t}}$ ; $\mathrm{R}_{\mathrm{T}, \mathrm{t}}$ notations as the dependent variables which represented the market return from Indonesia Stock Exchange, Singapore Stock Exchange, Kuala Lumpur Stock Exchange, and Stock Exchange Thailand respectively. Meanwhile, $\alpha_{n}$ notation with $n=$ four (4) was replaced with $\alpha_{\mathrm{I}, t} ; \alpha_{\mathrm{S}, \mathrm{t}} ; \alpha_{\mathrm{M}, \mathrm{t}} ; \alpha_{\mathrm{Th}, \mathrm{t}} \Theta_{\mathrm{nn}, \mathrm{k}} \mathrm{y}_{\mathrm{nt}-1}$ and t-1 as vector four (4) X one (1) was replaced with the following notations:

$$
\begin{aligned}
& {\left[\begin{array}{c}
\alpha_{\mathrm{II}} R_{\mathrm{I}, \mathrm{t}-1}+\alpha_{\mathrm{IS}} \mathrm{R}_{\mathrm{S}, \mathrm{t}-1}+\alpha_{\mathrm{IM}} \mathrm{R}_{\mathrm{M}, \mathrm{t}-1}+\alpha_{\mathrm{IT}} \mathrm{R}_{\mathrm{T}, \mathrm{t}-1} \\
\alpha_{\mathrm{SI}} \mathrm{R}_{\mathrm{S}, \mathrm{t}-1}+\alpha_{\mathrm{SS}} \mathrm{R}_{\mathrm{S}, \mathrm{t}-1}+\alpha_{\mathrm{SM}} \mathrm{R}_{\mathrm{M}, \mathrm{t}-1}+\alpha_{\mathrm{ST}} \mathrm{R}_{\mathrm{T}, \mathrm{t}-1} \\
\alpha_{\mathrm{MI}} \mathrm{R}_{\mathrm{M}, \mathrm{t}-1}+\alpha_{\mathrm{MS}} \mathrm{R}_{\mathrm{S}, \mathrm{t}-1}+\alpha_{\mathrm{MM}} \mathrm{R}_{\mathrm{M}, \mathrm{t}-1}+\alpha_{\mathrm{MT}} \mathrm{R}_{\mathrm{T}, \mathrm{t}-1} \\
\alpha_{\mathrm{TI}} \mathrm{R}_{\mathrm{T}, \mathrm{t}-1}+\alpha_{\mathrm{TS}} \mathrm{R}_{\mathrm{St}-1}+\alpha_{\mathrm{TM}} \mathrm{R}_{\mathrm{M}, \mathrm{t}-1}+\alpha_{\mathrm{TT}} \mathrm{R}_{\mathrm{T}, \mathrm{t}-1}
\end{array}\right]} \\
& {\left[\begin{array}{c}
\mathrm{R}_{\mathrm{I}, \mathrm{t}}=\alpha_{\mathrm{I}}+\alpha_{\mathrm{II}} \mathrm{R}_{\mathrm{I}, \mathrm{t}-1}+\alpha_{\mathrm{IS}} \mathrm{R}_{\mathrm{S}, \mathrm{t}-1}+\alpha_{\mathrm{IM}} \mathrm{R}_{\mathrm{M}, \mathrm{t}-1}+\alpha_{\mathrm{IT}} \mathrm{R}_{\mathrm{T}, \mathrm{t}-1}+\mathrm{e}_{\mathrm{I}, \mathrm{t}} \\
\mathrm{R}_{\mathrm{St}}=\alpha_{\mathrm{S}}+\alpha_{\mathrm{SI}} \mathrm{R}_{\mathrm{S}, \mathrm{t}-1}+\alpha_{\mathrm{SS}} \mathrm{R}_{\mathrm{S}, \mathrm{t}-1}+\alpha_{\mathrm{SM}} \mathrm{R}_{\mathrm{M}, \mathrm{t}-1}+\alpha_{\mathrm{ST}} \mathrm{R}_{\mathrm{T}, \mathrm{t}-1}+\mathrm{e}_{\mathrm{S}, \mathrm{t}} \\
\mathrm{R}_{\mathrm{M}, \mathrm{t}}=\alpha_{\mathrm{M}}+\alpha_{\mathrm{MI}} \mathrm{R}_{\mathrm{M}, \mathrm{t}-1}+\alpha_{\mathrm{MS}} \mathrm{R}_{\mathrm{S}, \mathrm{t}-1}+\alpha_{\mathrm{MM}} \mathrm{R}_{\mathrm{M}, \mathrm{t}-1}+\alpha_{\mathrm{MT}} \mathrm{R}_{\mathrm{T}, \mathrm{t}-1}+\mathrm{e}_{\mathrm{M}, \mathrm{t}} \\
\mathrm{R}_{\mathrm{T}, \mathrm{t}}=\alpha_{\mathrm{T}}+\alpha_{\mathrm{TI}} \mathrm{R}_{\mathrm{T}, \mathrm{t}-1}+\alpha_{\mathrm{TS}} \mathrm{R}_{\mathrm{S}, \mathrm{t}-1}+\alpha_{\mathrm{TM}} \mathrm{R}_{\mathrm{M}, \mathrm{t}-1}+\alpha_{\mathrm{TT}} \mathrm{R}_{\mathrm{T}, \mathrm{t}-1}+\mathrm{e}_{\mathrm{T}, \mathrm{t}}
\end{array}\right]}
\end{aligned}
$$


Cointegration test was carried out using Johansen's Multivariate Cointegration Test analysis. In addition, VECM analysis (Vector Correction Model) was also conducted to assess the availability of log term connections among the capital markets studied.

Equation (1) was then re-formulated into VECM form by subtracting $\mathrm{Z}_{\mathrm{t}-1}$ on both sides of equivalent:

$\Delta \mathrm{y}_{\mathrm{t}}=\alpha+\Gamma_{1} \Delta \mathrm{y}_{\mathrm{t}-1}+\ldots+\Gamma_{\mathrm{k}} \Delta \mathrm{y}_{\mathrm{t}-\mathrm{k}}+\Pi \mathrm{y}_{\mathrm{t}-1}+\varepsilon_{\mathrm{nt}}$

where, $\Delta \mathrm{y}_{\mathrm{t}}=\mathrm{y}_{\mathrm{t}}-\mathrm{y}_{\mathrm{t}-1} ; \Gamma_{1}=-\Theta_{2}-\Theta_{3} ; \Gamma_{2}=-\Theta_{3} ; \Pi=-\left(\mathrm{I}-\Theta_{1}-\ldots-\Theta_{\mathrm{k}}\right)$.

In addition, Granger Causality Test was added to reveal the contagion effect among the markets being studied. However, data stationarity test was required to be accomplished first prior to all those analyses. The stationarity test was accomplished by implementing Augmented Dickey-Fuller Test (ADF) method. Once the stationarity data were not achieved (unit root) then the degree of integration test needed to be done. It aimed to observe at what point the degree or differentiation order of the data was finally in the stationarity position.

Data. Secondary data obtained from the monthly closing of Jakarta Composite Index (JCI) in Jakarta Stock Exchange, Strait Times Index (STI) in Singapore Stock Exchange, KLSE Composite (KLSE) in Kuala Lumpur Stock Exchange, and SET index (SET) from Stock Exchange Thailand were used in this study. January 1997 to December 2013 was the period of data collection for this study.

For the January 1999 to December 2013 period, the data were acquired from Capital Market Statistics published by the Indonesia Financial Service Authority (FSA), while the KLSE Composite, Strait Time Index, and SET for January 1997 to December 1998 were obtained from their official websites. In addition, JCI data during January 1997 to December 1998 were collected form JSX Monthly Statistics on that period.

The data were then divided into three major periods to be analyzed. The periods were January 1997 to December 2013 or the overall period, July 1997 to September 2008 or post Asia financial crisis 1997 period, and October 2008 to December 2013 or post global financial crisis 2008 period.

\section{RESULTS}

Data Stationarity Test. The data stationarity test was accomplished by implementing Augmented Dickey-Fuller Test (ADF) method for level, first order, and second order. Once the stationarity data were not achieved (unit root) then the degree of integration test needed to be done. It aimed to observe at what point the degree or differentiation order of the data was finally in the stationarity position. The complete result of the overall period could be observed in Table 1, post Asia financial crisis period in Table 2, and post global financial crisis in Table 3.

The following three tables showed that the JCI, KLSE, SET, and STI variables had significant $t$ value for ADF test. In other words, unit root was not detected and the data was considered to be stationary. Thus, the hypothesis which claimed the unit root data was officially denied. 
Table 1. Augmented Dickey-Fuller tests statistic Period of January 1997 - December 2013

\begin{tabular}{lllll}
\hline Description & JCI & KLSE & SET & STI \\
\hline Level & $-12.01^{*}$ & $-12.57^{*}$ & $-12.66^{*}$ & $-13.41^{*}$ \\
1st Order & $-11.32^{*}$ & $-11.65^{*}$ & $-9.99^{*}$ & $-10.98^{*}$ \\
2nd Order & $-12.23^{*}$ & $-12.21^{*}$ & $-12.22^{*}$ & $-11.87^{*}$ \\
\hline
\end{tabular}

Source: Financial Service Authority, JSX Monthly Statistics and official related capital markets websites, processed.

Note:

* Significant at 1 percent level

Table 2. Augmented Dickey-Fuller tests statistic Period of July 1997 - September 2008

\begin{tabular}{lllll}
\hline Description & JCI & KLSE & SET & STI \\
\hline Level & $-9.93^{*}$ & $-10.21^{*}$ & $-11.79^{*}$ & $-10.48^{*}$ \\
1st Order & $-10.11^{*}$ & $-9.46^{*}$ & $-9.52^{*}$ & $-9.28^{*}$ \\
2nd Order & $-7.53^{*}$ & $-10.22^{*}$ & $-10.34^{*}$ & $-10.34^{*}$ \\
\hline
\end{tabular}

Source: Financial Service Authority, JSX Monthly Statistics and official related capital markets websites, processed.

Note: * Significant at 1 percent level

Table 3. Augmented Dickey-Fuller tests statistic Period of October 2008 - December 2013

\begin{tabular}{lllll}
\hline Description & JCI & KLSE & SET & STI \\
\hline Level & $-8.56^{*}$ & $-9.26^{*}$ & $-8.36^{*}$ & $-8.25^{*}$ \\
1st Order & $-11.79^{*}$ & $-6.73^{*}$ & $-11.89^{*}$ & $-9.63^{*}$ \\
2nd Order & $-6.83^{*}$ & $-10.01^{*}$ & $-9.76^{*}$ & $-5.02^{*}$ \\
\hline
\end{tabular}

Source: Financial Service Authority, JSX Monthly Statistics and official related capital markets websites, processed.

Note: * Significant at 1 percent level

Vector Autoregression Analysis / VAR (1). The VAR lag order selection using Schwartz Criterion (SC) showed that the optimum value for $\mathrm{k}=$ zero (0) for all periods in this research (January 1997 - December 2013, July 1997 - September 2008, and October 2008 - December 2013). Since the minimum k in VAR is one (1), thus VAR (1) was selected in analyzing this research. The results of capital markets integration analyses using Vector Autoregression (VAR) for January 1997 - December 2013 period, post Asia financial crisis 1997 period, and post global financial crisis 2008 period could be seen in the following Table 4, Table 5, and Table 6 respectively.

Table 4 showed the short term effects among the capital markets being studied. Here, Indonesia capital market was positively affected by Malaysia capital market at ten (10) percent of significance level and one (1) percent by Singapore capital market. These findings showed contradictions with the results found by Palac-McMiken (1997) and Roca et al. (1998) during the pre Asia financial crisis period and even with the researches done after the crisis like Suryanta (2011) who explained the absence of comovement among the 
Indonesia, Malaysia, and Singapore capital markets. In addition, this research also revealed that Malaysia capital market was positively influenced by Thailand (SET) at significance level five (5) percent and ten (10) percent by Singapore. At any point, Thailand capital market seemed to take the domination in the ASEAN region in short term conditions for it affected all the markets included Singapore at 5 percent of significance level, while the SET itself did not receive any effects from the other capital markets.

Table 4. Vector autoregression / VAR (1) results Period of January 1997 - December 2013

\begin{tabular}{lllll}
\hline Predictor & IHSG & KLSE & SET & STI \\
\hline IHSG(-1) & -0.02 & -0.02 & -0.03 & -0.10 \\
& {$[-0.25]$} & {$[-0.19]$} & {$[-0.29]$} & {$[-1.26]$} \\
KLSE(-1) & $0.18^{*}$ & -0.06 & 0.16 & 0.14 \\
& {$[1.87]$} & {$[-0.64]$} & {$[1.42]$} & {$[1.53]$} \\
SET(-1) & -0.07 & $0.15^{* *}$ & -0.02 & $0.19^{* *}$ \\
& {$[-0.85]$} & {$[1.96]$} & {$[-0.15]$} & {$[2.33]$} \\
STI(-1) & $0.31^{* * *}$ & $0.16^{*}$ & 0.04 & -0.04 \\
& {$[2.94]$} & {$[1.67]$} & {$[0.37]$} & {$[-0.39]$} \\
C & $0.01^{*}$ & 0.00 & 0.00 & 0.00 \\
& {$[1.96]$} & {$[0.69]$} & {$[0.95]$} & {$[0.79]$} \\
R-squared & 0.11 & 0.07 & 0.02 & 0.06 \\
Adj. R-squared & 0.09 & 0.06 & 0.00 & 0.04 \\
F-statistic & 6.32 & 3.91 & 0.89 & 2.89 \\
\hline Source: Finang
\end{tabular}

Source: Financial Service Authority, JSX Monthly Statistics and the official related capital markets websites, processed.

Note: Numbers in the brackets show t-statistic

* significant at 10 percent level

** significant at 5 percent level

*** significant at 1 percent level

The VAR (1) analysis of the post Asia financial crisis 1997 period could be seen in Table 5. Here, the effects during short term conditions among the capital markets in ASEAN region were found. In this period, Indonesia capital market was influenced by Malaysia at significance level ten (10) percent, and Singapore at five (5) percent. Meanwhile, Thailand seemed to be the only capital market which gave effects to Malaysia at significance level ten (10) percent and to Singapore capital market at five (5) percent of significance level. Once again, Thailand capital market took no influences from any of the other markets in ASEAN region. In addition, Singapore capital market was also negatively affected by Indonesia at ten (10) percent of significance level. 
Table 5. Vector autoregression (VAR) results Period of July 1997 - September 2008

\begin{tabular}{lllll}
\hline Predictor & IHSG & KLSE & SET & STI \\
\hline IHSG(-1) & -0.04 & -0.01 & -0.08 & $-0.16^{*}$ \\
& {$[-0.37]$} & {$[-0.14]$} & {$[-0.72]$} & {$[-1.63]$} \\
KLSE(-1) & $0.20^{*}$ & -0.06 & 0.17 & 0.14 \\
& {$[1.82]$} & {$[-0.53]$} & {$[1.34]$} & {$[1.35]$} \\
SET(-1) & -0.11 & $0.17^{*}$ & -0.04 & $0.19^{* *}$ \\
& {$[-1.08]$} & {$[1.70]$} & {$[-0.32]$} & {$[2.00]$} \\
STI(-1) & $0.34^{* * *}$ & 0.17 & -0.00 & -0.05 \\
& {$[2.74]$} & {$[1.38]$} & {$[-0.00]$} & {$[-0.46]$} \\
C & 0.01 & 0.00 & 0.004 & 0.005 \\
& {$[1.29]$} & {$[0.28]$} & {$[0.51]$} & {$[0.72]$} \\
R-squared & 0.13 & 0.07 & 0.02 & 0.06 \\
Adj. R-squared & 0.11 & 0.05 & -0.01 & 0.03 \\
F-statistic & 4.91 & 2.59 & 0.54 & 1.97 \\
\hline
\end{tabular}

Source: Financial Service Authority, JSX Monthly Statistics and the official related capital markets websites, processed.

Note:

Numbers in the brackets show t-statistic

* significant at 10 percent level

** significant at 5 percent level

*** significant at 1 percent level

A completely different result was found during the post global financial crisis 2008 period. In short term, none of the Indonesia, Malaysia, and Thailand capital markets affected one and another nor affected by other markets during this period. It showed evidences that those three markets were already segmented and were not influenced by the conditions of the other capital markets, especially in the ASEAN region. In this period, the domestic factors tended to be more dominant in determining the movements of the markets. A slightly different finding was found for Singapore capital market where significance level ten percent was still received from Malaysia in short term.

Table 6. Vector autoregression (VAR) results Period of October 2008 - December 2013

\begin{tabular}{lllll}
\hline Predictor & IHSG & KLSE & SET & STI \\
\hline IHSG(-1) & 0.01 & 0.08 & -0.01 & 0.18 \\
& {$[0.03]$} & {$[0.64]$} & {$[-0.04]$} & {$[0.86]$} \\
KLSE(-1) & 0.11 & -0.21 & 0.21 & $0.44^{*}$ \\
& {$[0.38]$} & {$[-1.25]$} & {$[0.73]$} & {$[1.67]$} \\
SET(-1) & 0.15 & -0.03 & -0.06 & -0.01 \\
& {$[0.71]$} & {$[-0.26]$} & {$[-0.30]$} & {$[-0.06]$} \\
STI(-1) & -0.07 & 0.11 & 0.18 & -0.27 \\
& {$[-0.32]$} & {$[0.84]$} & {$[0.79]$} & {$[-1.30]$} \\
\hline
\end{tabular}




\begin{tabular}{lllll}
\hline $\mathrm{C}$ & $0.02 * *$ & $0.01 * * *$ & $0.02 * *$ & 0.01 \\
& {$[2.33]$} & {$[3.05]$} & {$[2.36]$} & {$[0.73]$} \\
R-squared & 0.034 & 0.05 & 0.06 & 0.09 \\
Adj. R-squared & -0.033 & -0.02 & -0.00 & 0.04 \\
F-statistic & 0.506 & 0.69 & 0.96 & 1.56 \\
\hline
\end{tabular}

Source: Financial Service Authority, JSX Monthly Statistics and the official related capital markets websites, processed.

Note:

Numbers in the brackets show t-statistic

* significant at 10 percent level

** significant at 5 percent level

$* * *$ significant at 1 percent level

Capital Market Integration Analysis with Vector Error Correction Model / VECM. At this point, the analysis was done to scrutinize the long term balance within the capital market being studied. For the January 1997 - December 2013 period, the first cointegration coefficient was significant at level of confidence five percent and the second cointegration coefficient was at ten percent for Indonesia capital market. In other words, the long term integration between Indonesia and other capital markets would be specially depend on both cointegration coefficients. This VECM analysis also indicated that Indonesia capital market was negatively influenced by the first lags of JCI at significance level one percent and SET at significance level ten (10) percent, and STI also at one percent of significance level. The application of VAR in analyzing VECM gave significant distinctions mainly on the influences of Malaysia and Thailand capital markets. In VAR analysis, Malaysia capital market showed its short term influence toward Indonesia, while the similar influence was not observed for Thailand capital market. The opposite result was found in VECM for the analysis involved cointegration coefficients which played as impact counterweight in the long run.

Table 7. Vector error correction model results Period of January 1997 - December 2013

\begin{tabular}{lllll}
\hline Error Correction: & $\mathrm{D}(\mathrm{IHSG})$ & $\mathrm{D}(\mathrm{KLSE})$ & $\mathrm{D}(\mathrm{SET})$ & $\mathrm{D}(\mathrm{STI})$ \\
\hline CointEq1 & $-0.08^{* *}$ & $0.05 *$ & 0.05 & $-0.21 * * *$ \\
& {$[-2.06]$} & {$[1.78]$} & {$[1.41]$} & {$[-6.91]$} \\
CointEq2 & $0.32^{*}$ & $-0.84 * * *$ & $0.55 * * *$ & $0.58 * * *$ \\
& {$[1.86]$} & {$[-6.19]$} & {$[3.10]$} & {$[4.09]$} \\
D(IHSG(-1)) & $-0.29 * * *$ & -0.05 & -0.05 & 0.05 \\
& {$[-3.46]$} & {$[-0.69]$} & {$[-0.60]$} & {$[0.77]$} \\
D(KLSE(-1)) & -0.06 & -0.12 & -0.19 & $-0.27 * * *$ \\
& {$[-0.53]$} & {$[-1.37]$} & {$[-1.58]$} & {$[-2.87]$} \\
D(SET(-1)) & $-0.21^{*}$ & $-0.29 * * *$ & -0.05 & $-0.19 * *$ \\
& {$[-1.82]$} & {$[-3.39]$} & {$[-0.39]$} & {$[-2.11]$} \\
D(STI(-1)) & $0.40 * * *$ & -0.04 & -0.19 & 0.01 \\
& {$[3.33]$} & {$[-0.42]$} & {$[-1.52]$} & {$[0.10]$} \\
R-squared & 0.18 & 0.40 & 0.34 & 0.37 \\
Adj. R-squared & 0.16 & 0.38 & 0.33 & 0.35 \\
F-statistic & 8.67 & 26.04 & 20.47 & 22.74 \\
\hline Source: Finand
\end{tabular}

Source: Financial Service Authority, JSX Monthly Statistics and the official related capital markets websites, processed. 


\section{Note :}

Numbers in the brackets show t-statistic

* significant at 10 percent level

** significant at 5 percent level

*** significant at 1 percent level

For Malaysia capital market, the first cointegration coefficient was significant at ten percent level and the second was significant at one percent of significance level. The only influence toward Malaysia capital market was coming from Singapore in which its first lag of SET influenced negatively at significance level one percent. The application of VAR in analyzing VECM gave significant distinctions mainly on the influence of Singapore capital market toward Malaysia. In VAR analysis, Singapore capital market showed its short term influence toward Malaysia capital. However, the same influence was not observed for the long run due to the availability of counterweight instrument.

The second cointegration coefficient was significant at one percent for Thailand capital market. It indicated the long term connection between Thailand and the other capital markets. In addition, the short term impacts toward Thailand capital market from the other markets were not revealed. These VECM results were consistent with the findings of VAR (1) analysis.

Singapore capital market showed consistent cointegration coefficients for the first and the second at one percent of significance level. Singapore capital market was negatively influenced by both the first lag of KLSE at significance level one percent and also SET at five percent. These results were quite contrast to those found in VAR (1) analysis which revealed that SET index influenced Singapore capital market positively. It might occur due to the availability of counterweight intrument in the long run which explained the existence of Malaysia and Thailand capital markets toward Singapore.

The following Figure 1. showed the relation of cointegration among capital markets under this research during January 1997 to December 2013 period. It could be seen that the cointegration among the capital markets was very high during the Asia financial crisis 1997 period. However, the cointegration only sustained for a short period before it gradually declined since crisis until December 2013.
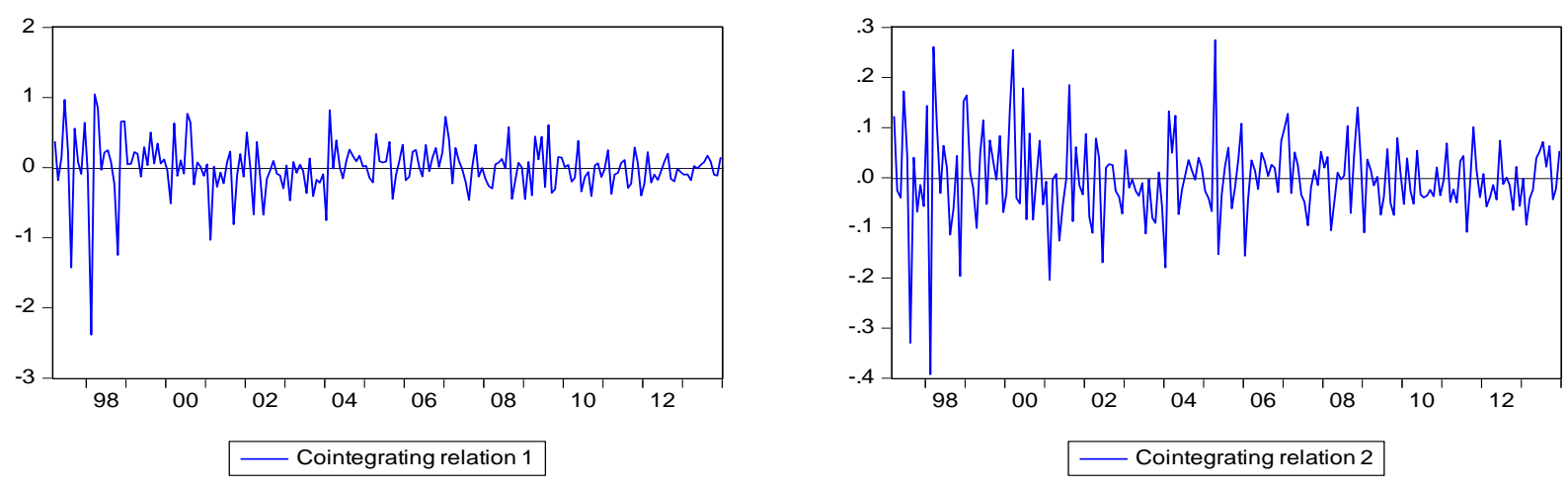

Figure 1. Cointegration for January 1997 - December 2013 period 
As shown in Table 8, the VECM analysis for July 1997 to September 2008 period showed significance level one percent of cointegration coefficient for Indonesia capital market. It indicated that the long run integration between Indonesia capital market and the other markets was determined by this cointegration coefficient. The Indonesia capital market was influenced by the first lag of JCI at significance level ten percent and it might happen for it was one of the most affected markets during the Asia financial crisis. Consequently, the market condition occurred the month before would significantly influence the condition on the next day. Besides, the first lags of Thailand and Singapore capital markets also gave effects toward Indonesia with one percent of significance level each. In VAR (1) analysis, Indonesia capital market also received effects from Singapore but not from Thailand. It happened for VECM involved cointegration coefficient which played as counterweight for short term impacts from those capital markets in the long run.

The second cointegration coefficient for Malaysia capital market was significant at one percent of significance level. This cointegration coefficient would then determine the long run integration between Malaysia and the other capital markets. The findings in both VECM and VAR (1) analyses for Malaysia capital market were consistent in which only the first lag of Thailand capital market gave significant influences toward Malaysia capital market. In VECM, the first lag of Thailand capital market significantly influenced Malaysia at significance level one (1) percent.

The second cointegration coefficient for Thailand capital market was at ten percent of significance level. It indicated the long run integration between Thailand capital market and the other markets would mainly determine by this cointegration coefficient. The VECM analysis showed zero influence from other capital markets toward Thailand. However, it still received effects from its own first lag at significance level ten percent which pointed out that the current market condition was mostly influenced by the condition on the month before, mainly by psychology aspect of the market. It might happen for Thailand was one of the most affected markets during the Asia financial crisis.

Table 8. Vector error correction model results Period of July 1997 - September 2008

\begin{tabular}{lllll}
\hline Error Correction: & D(IHSG) & D(KLSE) & D(SET) & D(STI) \\
\hline CointEq1 & $-0.30^{* * *}$ & -0.04 & 0.08 & $-0.45^{* * *}$ \\
& {$[-3.56]$} & {$[-0.57]$} & {$[0.91]$} & {$[-6.25]$} \\
CointEq2 & 0.17 & $-1.05^{* * *}$ & $0.36^{*}$ & $0.50^{* * * *}$ \\
& {$[0.87]$} & {$[-6.56]$} & {$[1.71]$} & {$[3.01]$} \\
D(IHSG(-1)) & $-0.18^{*}$ & -0.07 & -0.08 & 0.12 \\
& {$[-1.74]$} & {$[-0.80]$} & {$[-0.74]$} & {$[1.33]$} \\
D(KLSE(-1)) & -0.00 & -0.05 & -0.10 & $-0.27 * *$ \\
& {$[-0.00]$} & {$[-0.44]$} & {$[-0.76]$} & {$[-2.47]$} \\
D(SET(-1)) & $-0.44 * * *$ & $-0.34 * * *$ & $-0.25 *$ & $-0.23^{* *}$ \\
& {$[-3.52]$} & {$[-3.30]$} & {$[-1.83]$} & {$[-2.14]$} \\
D(STI(-1)) & $0.50^{* * *}$ & -0.15 & -0.09 & -0.06 \\
& {$[3.94]$} & {$[-1.39]$} & {$[-0.62]$} & {$[-0.55]$} \\
R-squared & 0.27 & 0.49 & 0.32 & 0.41 \\
Adj. R-squared & 0.25 & 0.47 & 0.30 & 0.39 \\
F-statistic & 9.62 & 24.35 & 12.12 & 17.96 \\
\hline
\end{tabular}

Source: Financial Service Authority, JSX Monthly Statistics and the official related capital markets websites, processed. 


\author{
Note: \\ Numbers in the brackets show t-statistic \\ * significant at 10 percent level \\ ** significant at 5 percent level \\ $* * *$ significant at 1 percent level
}

The both first and second cointegration coefficients for Singapore capital market were significant at one percent level. It indicated that these cointegration coefficients would determine the integration between Singapore capital market with other markets. The VECM analysis proved the availability of influences from the first lags of KLSE and SET at one percent of significance level each. This first lag of SET was consistent for both VAR (1) and VECM analyses, but different results were found for KLSE and JCI. It might happen due to the availability of counterweight instrument in the long run which explained the existence of influences from Malaysia capital market toward Singapore capital market.

The following Figure 2. showed the relation of cointegration among capital markets under this research during July 1997 to September 2013 period. It could be seen that the cointegration among the capital markets was very high during the Asia financial crisis 1997 period. However, the cointegration tended to be declining until the mid of 2013 that then turned to be relatively stable for the next following years with smaller degree of cointegration in the early periods after the Asia financial crisis.
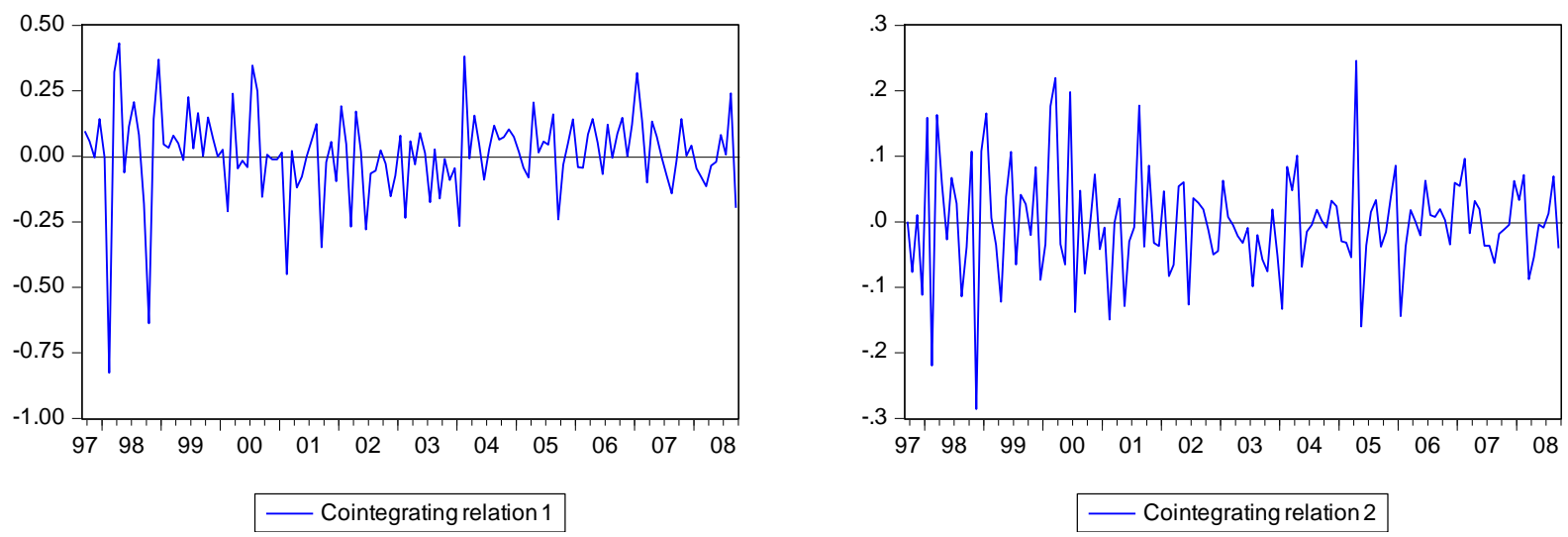

Figure 2. Cointegration for July 1997 - September 2008 period

Table 9. showed the results of VECM analysis for October 2008 to December 2013 period which indicated the first cointegration coefficient of Indonesia capital market was significant at ten percent of significance level, while the second cointegration coefficient was at one percent. It means that the long run integration between Indonesia capital market with other markets would be adjusted with those cointegration coefficients. Furthermore, Indonesia capital market also received influences of the first lags from KLSE at five percent of significance level and from STI at ten percent. The results were completely different with the findings in VAR (1) analysis which showed zero influence toward Indonesia from any other capital markets during this period. It happened due to the 
availability of counterweight instrument in the long run which explained the influences of Malaysia and Singapore markets toward Indonesia capital market.

Table 9. Vector error correction model results Period of October 2008 - December 2013

\begin{tabular}{lllll}
\hline Error Correction: & D(IHSG) & D(KLSE) & D(SET) & D(STI) \\
\hline CointEq1 & $-0.73 *$ & 0.31 & 0.57 & 0.41 \\
& {$[-1.83]$} & {$[1.29]$} & {$[1.60]$} & {$[1.13]$} \\
CointEq2 & $1.33 * * *$ & -0.23 & $1.22^{* * *}$ & 0.39 \\
& {$[3.35]$} & {$[-0.95]$} & {$[3.42]$} & {$[1.08]$} \\
D(IHSG(-1)) & 0.06 & -0.05 & -0.28 & 0.01 \\
& {$[0.21]$} & {$[-0.29]$} & {$[-1.15]$} & {$[0.028]$} \\
D(KLSE(-1)) & $-0.59 * *$ & $-0.46^{* *}$ & $-0.47 *$ & 0.13 \\
& {$[-1.97]$} & {$[-2.54]$} & {$[-1.77]$} & {$[0.47]$} \\
D(SET(-1)) & 0.36 & 0.09 & $0.53 * *$ & $0.44^{* *}$ \\
& {$[1.48]$} & {$[0.57]$} & {$[2.40]$} & {$[1.98]$} \\
D(STI(-1)) & $-0.30 *$ & 0.02 & -0.02 & $-0.74 * * *$ \\
& {$[-1.7]$} & {$[0.22]$} & {$[-0.12]$} & {$[-4.72]$} \\
R-squared & 0.27 & 0.30 & 0.40 & 0.35 \\
Adj. R-squared & 0.21 & 0.23 & 0.35 & 0.30 \\
F-statistic & 4.17 & 4.64 & 7.35 & 6.03 \\
\hline
\end{tabular}

Source: Financial Service Authority, JSX Monthly Statistics and the official related capital markets websites, processed.

Note:

Numbers in the brackets show t-statistic

* significant at $10 \%$ level

** significant at $5 \%$ level

$* * *$ significant at $1 \%$ level

Significant cointegration coefficient was not detected for Malaysia capital market (KLSE). The only influence toward KLSE came from the first lag of KLSE itself. Similar results were also showed for VAR analysis. Therefore, Malaysia capital market considered to be more and more segmented and tended to be influenced only from domestic factors during the post global financial crisis 2008 period. The second cointegration coefficient gave significant effect toward Thailand capital market (SET) at one percent of significance level. It assumed that the long run integration between Thailand capital markets and other markets would be mostly determined by this cointegration coefficient. The only capital market which gave significant influence toward Thailand was the first lag of Malaysia capital market (KLSE) at ten percent of significance level. Besides, its own first lag of SET also gave significant effect at five percent level.

There was no significant cointegration coefficient found for Singapore capital market (STI). Hence, it was found that the first lags of STI and Thailand capital market (SET) had significant effects toward STI. The existence of long run counterweight model which showed zero effect of Thailand capital market in VAR model turned significant in 
VECM. A slightly different for Malaysia capital market, it showed significant effect in VAR (1) model, but turned the opposite in VECM.

The following Figure 3. showed the relation of contegration among capital markets under this research during October 2008 to December 2013 period. It could be seen that the capital markets cointegration was very high during the early period of global financial crisis 2008. However, the cointegration tended to be declining until the mid of 2010 that then turned to be relatively stable for the next following years with smaller degree of cointegration in the early periods after the global financial crisis 2008.
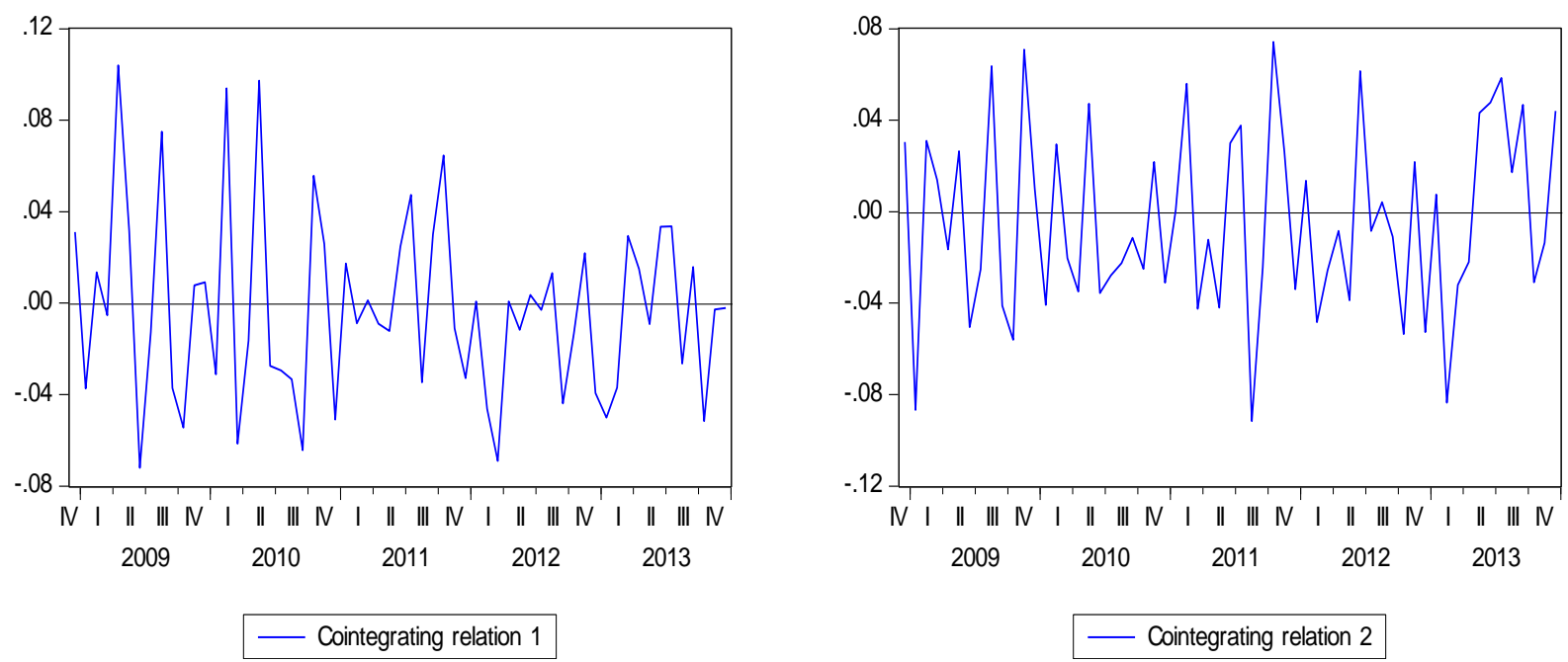

Figure 3. Cointegration for October 2008 - December 2013 period

Johansen's Multivariate Cointegration Test. Johansen's Multivariate Cointegration Test applied indicated the long run cointegration relation among all markets under this study during July 1997 to December 2013 period. However, the analysis on this test has a shortcoming in which cannot show which capital market is the leader and which one is the follower. As an attempt to complete the analysis, Granger Causality Test would be then elaborate on the next following section.

Table 10. Results of Johansen's multivariate cointegration test with trace

\begin{tabular}{lllll}
\hline $\begin{array}{l}\text { Hypothesized } \\
\text { No. of CE }(\mathrm{s})\end{array}$ & Eigenvalue & $\begin{array}{l}\text { Trace } \\
\text { Statistic }\end{array}$ & $\begin{array}{l}\text { Critical Value } \\
\text { None } *\end{array}$ & Prob. ${ }^{* *}$ \\
\hline At most $1 *$ & 0.49 & 430.37 & 40.17 & 0.00 \\
At most $2 *$ & 0.45 & 295.01 & 24.28 & 0.00 \\
At most $3 *$ & 0.44 & 173.09 & 12.32 & 0.00 \\
& 0.25 & 58.13 & 4.13 & 0.00 \\
\hline
\end{tabular}

Source: Financial Service Authority, JSX Monthly Statistics and official related capital markets websites, processed. 
Table 11. Results Johansen's multivariate cointegration test with Max-Eigen

\begin{tabular}{lllll}
\hline $\begin{array}{l}\text { Hypothesized } \\
\text { No. of CE(s) }\end{array}$ & Eigenvalue & $\begin{array}{l}\text { Max-Eigen } \\
\text { Statistic }\end{array}$ & $\begin{array}{l}0.05 \\
\text { Critical Value }\end{array}$ & Prob.** \\
\hline None $*$ & 0.49 & 135.36 & 24.16 & 0.00 \\
At most $1 *$ & 0.45 & 121.92 & 17.79 & 0.00 \\
At most $2 *$ & 0.44 & 114.96 & 11.22 & 0.00 \\
At most $3 *$ & 0.25 & 58.13 & 4.13 & 0.00 \\
\hline
\end{tabular}

Source: Financial Service Authority, JSX Monthly Statistics and official related capital markets websites, processed.

Contagion Effect Analysis with Granger Causality Test. Granger Causality Test applied in this study for all the three periods (January 1997 to December 2013, July 1997 to September 2008, and October 2008 to December 2013) indicated some interesting patterns as follows:

Table 12. Granger causality test results

\begin{tabular}{|c|c|c|c|c|c|c|c|c|c|}
\hline \multirow[t]{2}{*}{ Description } & \multicolumn{3}{|c|}{$\begin{array}{l}\text { January } 1997 \text { - December } \\
2013\end{array}$} & \multicolumn{3}{|c|}{$\begin{array}{l}\text { July } 1997 \text { - September } \\
2008\end{array}$} & \multicolumn{3}{|c|}{$\begin{array}{l}\text { October } 2008 \text { - December } \\
2013\end{array}$} \\
\hline & Obs & F-Statistic & Prob. & Obs & $\begin{array}{l}\text { F- } \\
\text { Statistic }\end{array}$ & Prob. & Obs & $\begin{array}{l}\text { F- } \\
\text { Statistic }\end{array}$ & Prob. \\
\hline $\mathrm{KLSE} \rightarrow \mathrm{JCI}$ & 203 & 10.09 & 0.00 & 134 & 9.15 & 0.00 & 62 & 0.15 & 0.70 \\
\hline $\mathrm{JCI} \rightarrow \mathrm{KLSE}$ & & 2.32 & 0.13 & & 1.11 & 0.29 & & 2.07 & 0.16 \\
\hline $\mathrm{SET} \rightarrow \mathrm{JCI}$ & 203 & 1.16 & 0.28 & 134 & 0.59 & 0.44 & 62 & 0.49 & 0.48 \\
\hline $\mathrm{JCI} \rightarrow \mathrm{SET}$ & & 0.08 & 0.78 & & 0.10 & 0.75 & & 0.61 & 0.44 \\
\hline $\mathrm{STI} \rightarrow \mathrm{JCI}$ & 203 & 15.12 & 0.00 & 134 & 12.91 & 0.00 & 62 & 0.00 & 0.98 \\
\hline $\mathrm{JCI} \rightarrow \mathrm{STI}$ & & 0.00 & 0.99 & & 0.31 & 0.58 & & 2.71 & 0.11 \\
\hline $\mathrm{SET} \rightarrow \mathrm{KLSE}$ & 203 & 9.74 & 0.00 & 134 & 6.56 & 0.01 & 62 & 0.96 & 0.33 \\
\hline $\mathrm{KLSE} \rightarrow \mathrm{SET}$ & & 2.76 & 0.09 & & 1.64 & 0.20 & & 1.56 & 0.22 \\
\hline $\mathrm{STI} \rightarrow \mathrm{KLSE}$ & 203 & 8.39 & 0.00 & 134 & 5.32 & 0.02 & 62 & 2.38 & 0.13 \\
\hline $\mathrm{KLSE} \rightarrow \mathrm{STI}$ & & 3.16 & 0.07 & & 1.95 & 0.16 & & 4.63 & 0.04 \\
\hline STI $\rightarrow$ SET & 203 & 0.89 & 0.35 & 134 & 0.17 & 0.68 & 62 & 1.72 & 0.19 \\
\hline $\mathrm{SET} \rightarrow \mathrm{STI}$ & & 5.58 & 0.02 & & 3.34 & 0.07 & & 0.89 & 0.35 \\
\hline
\end{tabular}

Source: Financial Service Authority, JSX Monthly Statistics and the official related capital markets websites, processed.

For January 1997 to December 2013, the test indicated a contagion effect from KLSE to JCI. However, the otherwise pattern, i.e. from JCI to KLSE, was not detected. The same patterns also appeared between STI and JCI. A slightly different pattern was found between JCI and SET in which contagion effect did not found between both. The results indicated that contagion effect among those markets was not mainly caused by the different transaction times. As explained, Singapore Stock Exchange which started earlier was, in fact, affected by Stock Exchange Thailand which started later after. Similar Granger Causality Test results were also found for post Asia financial crisis 1997, but here the contagion effects from SET and STI toward KLSE were not detected. 
In addition, during post global financial crisis 2008 period, dramatically changes also occurred in terms of the interrelationship among ASEAN's capital markets. After the crisis, the contagion effects which were clearly seen during pre crisis period were barely detected and tended to disappear. The only contagion effect visible was from KLSE to STI which was surprisingly inversely proportional to the post Asia financial crisis 1997 where the contagion effect came from STI to KLSE.

\section{CONCLUSION}

Comovement was clearly seen among Indonesia, Malaysia, Thailand, and Singapore capital markets during this period of research (January 1997 - December 2013). The comovement was still detected during post Asia financial crisis 1997 period and post global financial crisis 2008 period.

During post Asia financial crisis 1997 period, Indonesia capital market received contagion effects from both Malaysia and Singapore capital markets. However, the same contagion effects from Thailand, Malaysia, and Singapore capital markets were not found during post global financial crisis 2008 period. The similar patterns, in general, were also found for Malaysia, Thailand, and Singapore capital markets during post global financial crisis 2008 period. The conditions might happen since the capital markets under this research were severely suffered during Asia financial crisis. The effects tended to be endemic in the one area which was triggered by Thailand crisis. Compared to the 1997 crisis, global financial crisis 2008 gave temporary and minor impacts toward ASEAN member countries.

The findings indicated that capital markets integration among ASEAN member countries tended to be much stronger during the regionally turbulences occurred for investors tended to keep focus only on one area that the turbulences would only influence the regional market. Conversely, the integration tended to be fading away during the internationally turbulences happened for each capital markets were busy to maintain their own positions from the turbulences. Moreover, most investors tended to give more concerns to global conditions than the regional ones. Furthermore, stronger economy fundamentals in almost all ASEAN countries during global financial crisis 2008 compared to the preceding 1997 crisis also gave significant contributions toward the different situations. Last but not least, ASEAN capital markets received more effects from the domestic factors than the external ones and tended to be more segmented during post global financial crisis 2008 period.

Shortly, this study concluded that the integration among some ASEAN capital markets tended to gradually fade away through times. The integration looked quite improving in the early periods of Asia financial crisis 1997 and global financial crisis 2008 periods, but then gradually declining over times. For the investors, this declining level of integration may allowing them to formulate a better diversified portfolio. Investors able to formulate a portfolio which consist of stocks across the ASEAN capital markets. 


\section{REFERENCES}

Baele, L., Ferrando, A., Hordahl, P., Krylova, E., \& Monnet, C. (2004). Measuring Financial Integration in The Euro Area. European Central Bank Occasional Paper Series, 14.

Bekaert, G., Harvey, C. R., \& Lundblad, C. (2007). "Global Growth Opportunities and Market Integration". Journal of Finance, 62(3), 1081-1137.

Bilson, C. (2000). The Impact of Liberalization and Regionalism upon Capital Markets in Emerging Asian Economics. Asian Financial Crisis: Structural and International Dimensions, International Finance Review 1.

Ibrahim, M. H. (2006). International Linkage of ASEAN Stock Prices: An Analysis of Response Asymmetries. Applied Econometrics and International Development, 3(3), 191-202.

Jorion, P., \& Schwartz, E. (1986). "Integration vs. Segmentation in the Canadian Stock Market". Journal of Finance, 41(3), 603-614.

Karim, B. A., \& Karim, Z. A. (2012). "Integration of ASEAN-5 Stock Markets: A Revisit". Asian Academyof Management Journal of Accounting and Finance, 8(2), 21-41.

Kenani, J. M., Purnomo, J., \& Maoni, F. (2013). "The Impact of the Global Financial Crisis on the Integration of the Chinese and Indonesian Stock Markets". International Journal of Economics and Finance, 5(9), 69-81.

Mulyadi, M. S. (2012). "Analysis of Volatility Spillover in Indonesia, USA and Japan Capital Market". African Journal of Business Management, 6(27). doi: 10.5897/ajbm11.2054

Palac-McMiken, E. D. (1997). "An Examination of ASEAN Stock Markets: A Cointegration Approach". ASEAN Economic Bulletin, 13(3), 299-311.

Robiyanto, R. (2017). "The Analysis of Capital Market Integration in ASEAN Region by Using the OGARCH Approach". Jurnal Keuangan dan Perbankan, 21(2), 169175.

Robiyanto, R., Hersugondo, H., \& Chotijah, G. S. (2016). "ASEAN Economic Community (AEC) and Economic Stability: A Review from Indonesia's Side". International Journal of Economic Research, 13(2).

Robiyanto, R., Wahyudi, S., \& Pangestuti, I. R. D. (2017a). "Testing Commodities as Safe Haven and Hedging Instrument on ASEAN's Five Stock Markets", Jurnal Ekonomi Kuantitatif Terapan, 10(2). doi: https://doi.org/10.24843/JEKT.2017.v10.i02.p11

Robiyanto, R., Wahyudi, S., \& Pangestuti, I. R. D. (2017b). "The volatility-variability hypotheses testing and hedging effectiveness of precious metals for the Indonesian and Malaysian capital markets". Gadjah Mada International Journal of Business, 19(2), 167-192. doi: 10.22146/gamaijb.26260

Roca, E. D., Selvanathan, E. A., \& Shepherd, W. F. (1998). "Are the ASEAN Equity Markets Interdependent?", ASEAN Economic Bulletin, 15(2), 109-120.

Suganda, T. R., \& Soetrisno, Y. (2016). "Uji Integrasi dan Contagion Effect Pasar Modal Pada Lima Negara ASEAN (Riset Empiris Pasca Terjadinya Krisis Subprime Mortgage dan Krisis Yunani)". Jurnal Keuangan dan Perbankan, 20(2), 252-262. 
Suryanta, B. (2011). "Capital Market Integration in ASEAN Countries: Special Investigation of Indonesian Towards the Big Four". Asian Journal of Technology Management, 4(2), 109-114.

Valle, R. S. (2000). A Cointegration Analysis of Latin American Stock Markets and The U.S. SSRN Working Paper.

Volz, U. (2013). "ASEAN Financial Integration in the Light of Recent European Experiences". Journal of Southeast Asian Economics, 30(2), 124-142.

Weber, A. A. (2006). European Financial Integration and (its Implications for) Monetary Policy. Paper presented at the Annual General Meeting 2006 of the Foreign Bankers' Association in the Netherlands, Amsterdam. 